\title{
Astronomy and astronomers in Jules Verne's novels
}

\author{
Jacques Crovisier \\ Observatoire de Paris, \\ 5 place Jules Janssen, 92195 Meudon, France \\ email: jacques.crovisier@obspm.fr
}

\begin{abstract}
Almost all the Voyages Extraordinaires written by Jules Verne refer to astronomy. In some of them, astronomy is even the leading theme. However, Jules Verne was basically not learned in science. His knowledge of astronomy came from contemporaneous popular publications and discussions with specialists among his friends or his family. In this article, I examine, from the text and illustrations of his novels, how astronomy was perceived and conveyed by Jules Verne, with errors and limitations on the one hand, with great respect and enthusiasm on the other hand. This informs us on how astronomy was understood by an "honnête homme" in the late 19 th century.
\end{abstract}

Keywords. Verne J., literature, 19th century

\section{Introduction}

Jules Verne (1828-1905) wrote more than 60 novels which constitute the Voyages Extraordinaires seriest. Most of them were scientific novels, announcing modern science fiction. However, following the strong suggestions of his editor Pierre-Jules Hetzel, Jules Verne promoted science in his novels, so that they could be sold as educational material to the youth (Fig. 1). Jules Verne had no scientific education. He relied on popular publications and discussions with specialists chosen among friends and relatives.

This article briefly presents several examples of how astronomy appears in the text and illustrations of the Voyages Extraordinaires. Further information can be found in Bacchus (1992), Crovisier (2005a), Sauzereau \& Giton (2006) and http://www.lesia. obspm.fr/perso/jacques-crovisier/JV/verne_gene_eng.html

\section{Astronomical voyages}

Several novels of Jules Verne explicitly refer to astronomy (Table 1). In them, the story line is occasionally interrupted by full pages, or even chapters, devoted to didactic explanations of astronomical topics. In addition, almost all other novels of the series contain episodic references to astronomy or connected sciences. In particular, determining the ship's bearing is a recurrent affair. Jules Verne was an amateur sailor himself (he successively owned three yachts). His brother Paul (1829-1897) had a certificate of master mariner and advised him for navigation matters.

De la Terre à la Lune (From the Earth to the Moon) and Autour de la Lune (Around the Moon) are probably the most famous novels on lunar exploration. Jules

$\dagger$ An authoritative biography of Jules Verne in English was recently published by Butcher (2006). 


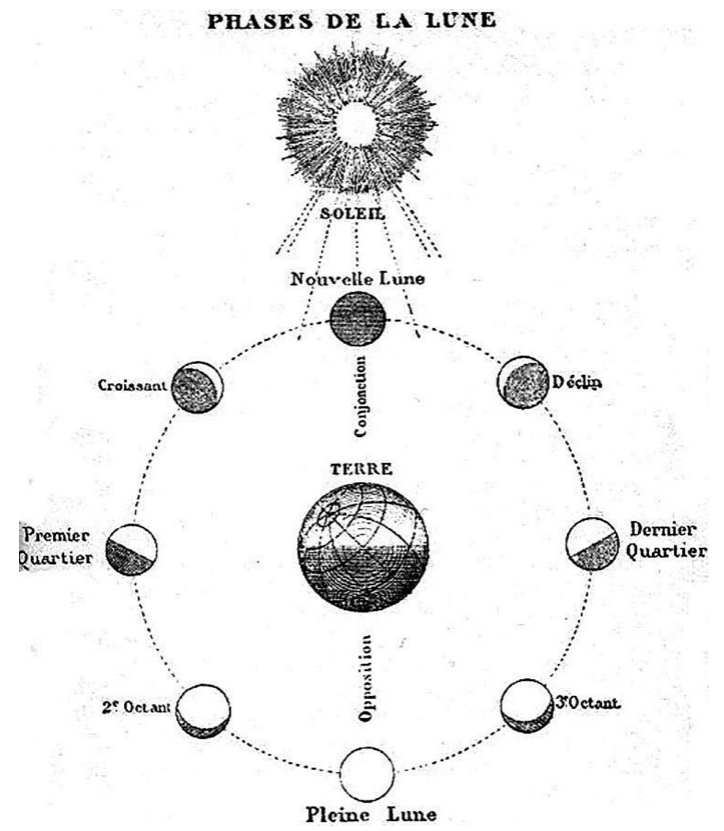

Figure 1. The phases of the Moon, a didactic illustration of From the Earth to the Moon.

Verne required the advice of his cousin Henri Garcet (1815-1871), a professor of mathematics in Paris who published Leçons nouvelles de cosmographie (Garcet 1854), a textbook on astronomy which was popular for several decades. Garcet's former colleague Joseph Bertrand (1822-1900), a distinguished mathematician and academician, also helped.

In Around the Moon, the projectile on its way to the Moon flies by a meteor, which is identified as the "second satellite of the Earth" of M. Petit. Indeed, Frédéric Petit (18101865), founder and director of Toulouse Observatory, studied the orbits of meteors and suggested that one of them could be a second satellite of the Earth (Kragh 2009). This hypothesis was soon abandoned due to the uncertainty on the determination of the orbit of such bodies. Jules Verne probably did not read the original reports of Petit (published in the Comptes-rendus), but took the information from the popular book of Amédée Guillemin (1826-1893) on the Moon (Guillemin 1866).

Aventures de trois Russes et de trois Anglais dans l'Afrique australe (Adventures of Three Russians and Three Britons in Southern Africa) transposes in Africa the great astronomical expeditions to measure arcs of meridian (Fig. 2a). A multinational team of astronomers strive to accomplish their mission in hostile conditions. This is a tribute to François Arago. Jules Verne also acknowledges his cousin H. Garcet, by reproducing a page of his Cosmographie explaining triangulation.

Le Pays des Fourrures (The Fur Country) relates the failed observation of the 18 July 1860 solar eclipse in the American far North (Fig. 2b). Several expeditions were indeed organized to observe this eclipse, especially in Spain and Africa, but the eclipse was not total in The Fur Country!

Le Tour du monde en quatre-vingt jours (Around the World in Eighty Days), which deals with the oddities of the change of date when travelling around the world, 
Table 1. Novels of Jules Verne with references to astronomy. The date is that of the first Hetzel edition. Many variants exist for the English titles.

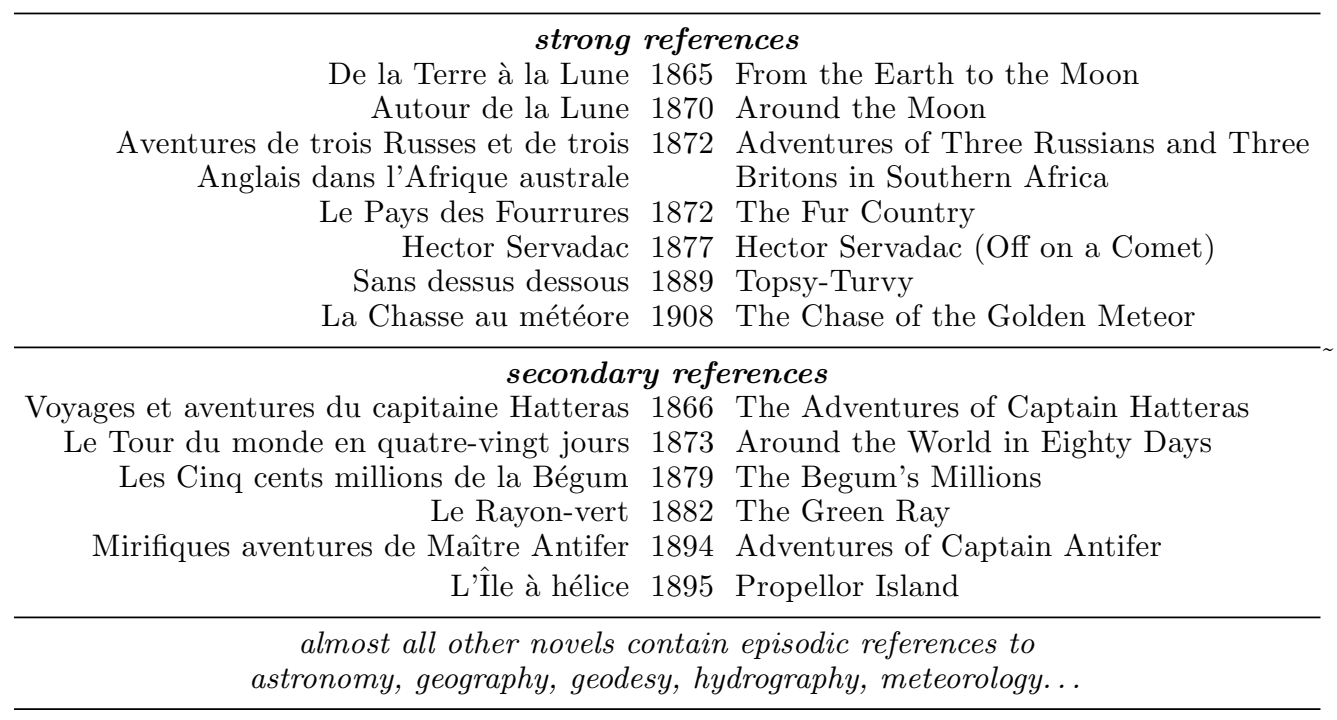

is presented as a "cosmographic joke" by J. Verne himself. It was prompted to him by Edgar A. Poe's (1809-1849) short story Three Sundays in a Week. (However, this curiosity was already remarked in 1524 by the companions of Magellan in their diary.) This story is at the origin of a talk on meridians and calendars at the Société géographique in Paris, resulting to the only scientific publication by Verne (1873).

Le Rayon-vert (The Green Flash) is an exemplary case of the synergy between science and Jules Verne. We still ignore when, where and how Jules Verne learned of the green flash (O'Connell 1958). But its report in this novel† indeed triggered research on this atmospheric phenomenon, previously unknown to the layman!

Hector Servadac tells the voyage across the Solar System aboard a comet of a small community, including the free-lance astronomer Palmyrin Rosette (Fig. 3a). It prefigures the Voyager missions of the NASA which flew-by successively several planets, as well as the ongoing Rosetta mission of ESA towards comet $67 \mathrm{P} /$ Churyumov-Gerasimenko (Crovisier 2005b).

When working on this novel, Jules Verne reduced the orbital period of the comet which crossed the orbits of Venus and Jupiter - to two years, in obvious contradiction with Kepler's laws.

Sans dessus dessous (Topsy-Turvy) is a foolish attempt to tilt the rotation axis of the Earth, using the recoil effect of a giant cannon. The attempt fails, due to a miscalculation. The story is based upon a sound technical study (Badoureau 2005).

Albert Badoureau (1853-1923), a mining engineer, lived in Amiens from 1884 to 1894 where he was meeting Jules Verne at the Société industrielle and the Académie. He was commissioned (and paid) by Jules Verne to provide the scientific background of TopsyTurvy. Indeed, one of the characters of this novel — Alcide Pierdeux — is sketched after Badoureau. The study of Badoureau was published in extenso, packed with formulas and scientific drawings, as the last chapter in the first edition of the novel.

$\dagger$ It is also mentioned in four other novels of the Voyages Extraordinaires series. 

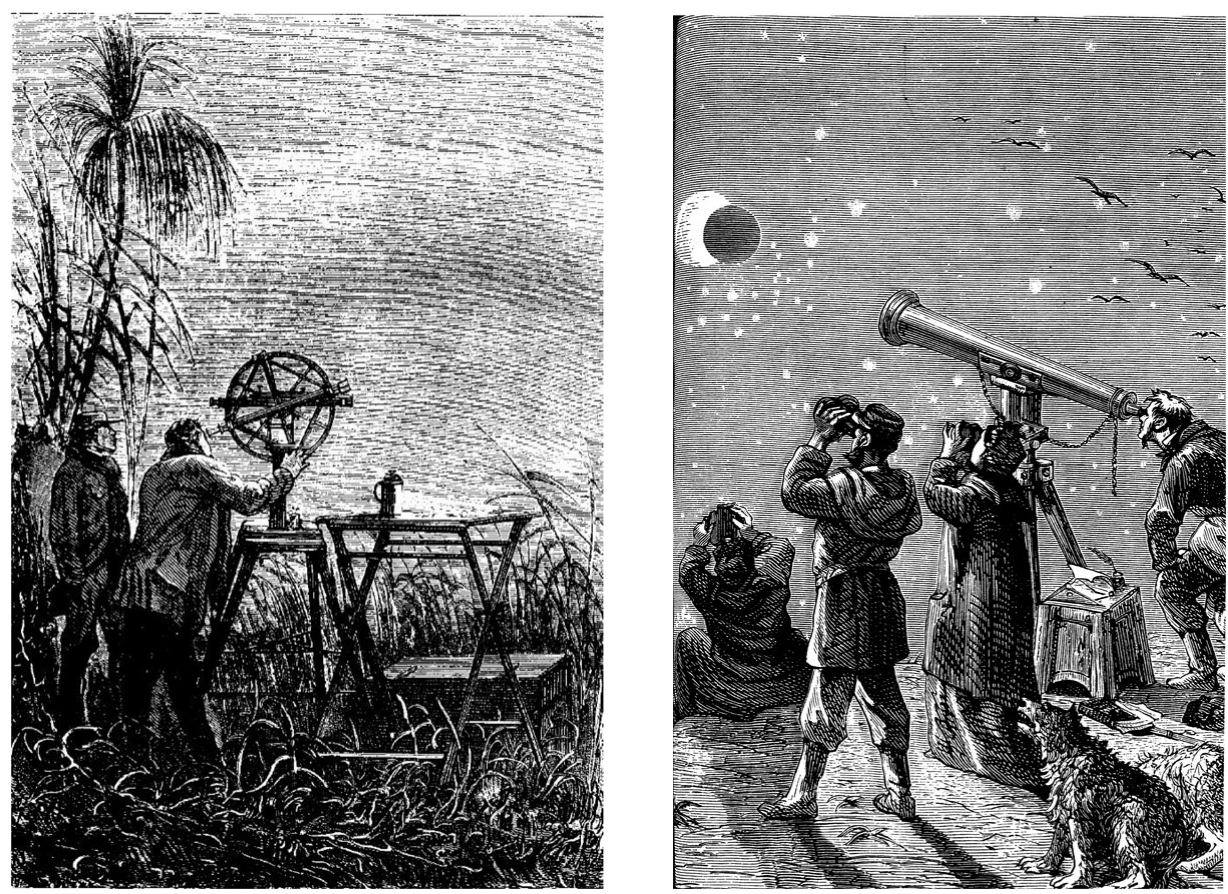

Figure 2. Astronomers at work from illustrations of Jules Verne's novels. Left (a): Measurement of an arc of meridian (drawing by J. Férat, from Adventures of three Russians and three Britons in Southern Africa"). Right (b): Observation of a solar eclipse in the American far North (drawing by J. Férat, from The Fur Country).

La Chasse au météore (The Chase of the Golden Meteor), a posthumous novel rewritten by Jules Verne's son Michel (1861-1925), narrates the rivalry between two amateur astronomers who both discovered a bolid (in fact an asteroid). The asteroid (like the comet in Hector Servadac) is made of gold, and the announcement of its fall on Earth provokes a financial crisis.

One can remark that the orbital elements of the asteroid (both those given in the original Jules' version or the rewritten Michel's version) do not fit with Kepler's laws. That was also the case for the bolid of Around the Moon.

One of the additions of Michel Verne to the original text of his father was the introduction of a new character. Zéphyrin Xirdal is an absent-minded scientist, not unlike Alcide Pierdeux in Topsy-Turvy. He used a device based on the equivalence between mass and energy to deviate the orbit of the asteroid. Michel had probably heard of the new ideas of Einstein, which were emerging at that time (1907).

\section{Conclusion}

Verne had a very high opinion of astronomy and astronomers. For him, "an astronomer is more than human, since he lives away from the Earth" $\dagger$. François Arago was his idol (Le Lay 2005). Astronomers are described in his novels as proficient professionals, somewhat between absent-minded scientists and mad scientists (Fig. 3).

There are basically no inventions in Verne's novels. Fantasy is not present; for instance, the controversial question of the existence of Martians is carefully avoided (which is

$\dagger$ "Un astronome est plus qu'un homme, puisqu'il vit en dehors du monde terrestre" (Hector Servadac, part II, chap. XIX). 

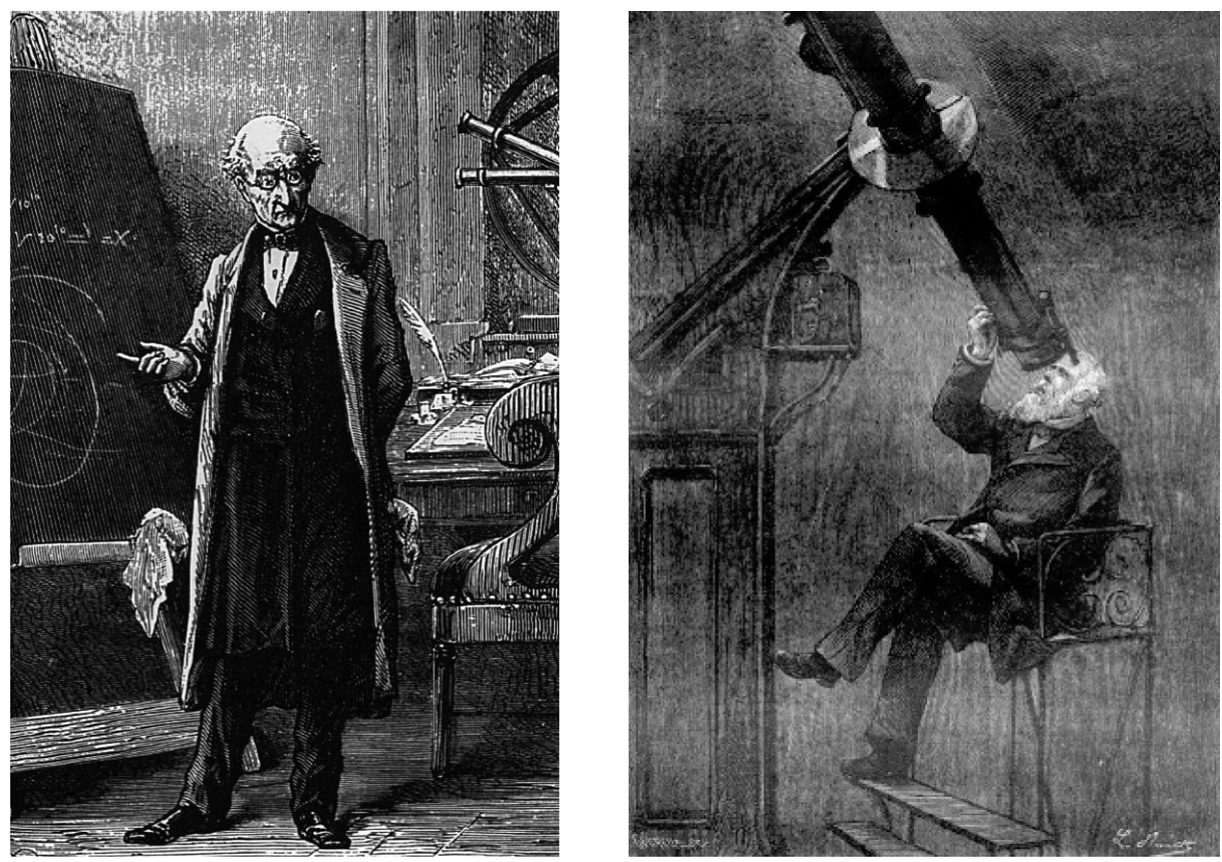

Figure 3. Portraits of astronomers in Jules Verne's novels. Left (a): An irascible astronomer, Palmyrin Rosette (drawing by P. Philippoteaux, from Hector Servadac). Right (b): A kind astronomer, the former king of Malécarlie, modelled after the emperor of Brazil Dom Pedro II (drawing by L. Benett, from L'Île à hélice (Propellor Island)).

not the case in the popular books of Camille Flammarion (1842-1925), Verne's rival in literature).

Jules Verne extrapolated from existing techniques and machines. He naïvely assumed that instrumental performances linearly scale as the size (as for the telescope in Around the Moon; Fig. 4), or that the accuracy of measurements can be infinitely improved by the repetition of observations (as in Adventures of Three Russians and Three Britons in Southern Africa).

Some of the ideas of Jules Verne are still quite pertinent today. For instance, in The Adventures of Captain Hatteras, Dr Clawbonny — an eclectic character who discourses on various scientific topics for the benefit of the reader - tells:

Comets are the deus ex machina; every time you're embarrassed in cosmography, you bring in a comet. It is the most helpful heavenly body I know, for at the slightest sign from scientists, it does its level best to fix everything. $\dagger$

Jules Verne had in mind the changes of the spin axis of the Earth induced by cometary impacts on the Earth, leading to climatic changes. He would be amused to learn that still nowadays, comets are invoked to explain the origin of water on Earth, the emergence of life, or the queer properties of circumstellar discs.

$\dagger$ 'La comète est le Deus ex machina ; toutes les fois qu'on est embarrassé en cosmographie, on appelle une comète à son secours. C'est l'astre le plus complaisant que je connaisse, et, au moindre signe d'un savant, il se dérange pour tout arranger !" (Voyages et aventures du capitaine Hatteras, 1866, Part 2, Chap. 14). 


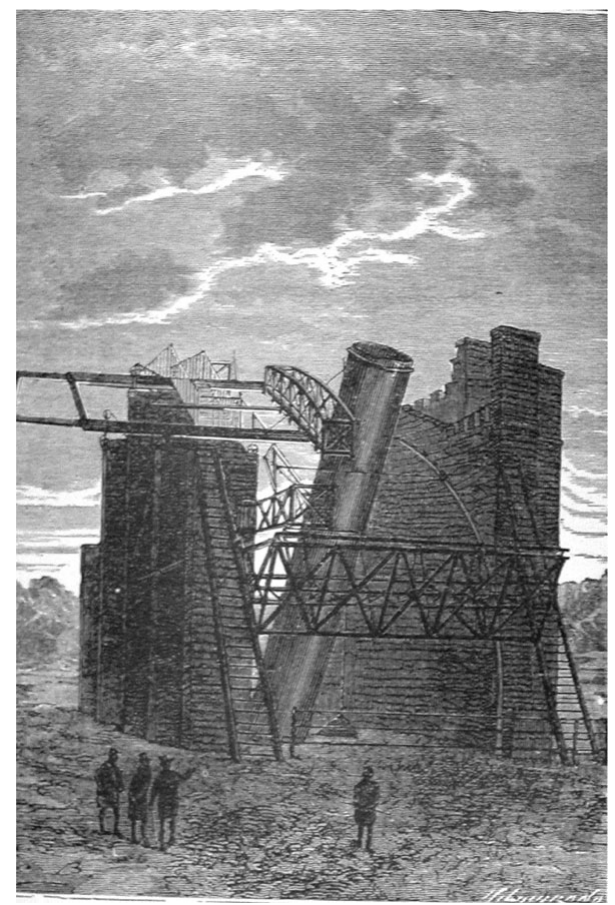

Figure 4. The 16-feet telescope of Long's Peak observatory, in Around the Moon, was designed as an enlargement of the 6-feet telescope of Lord Rosse (William Parsons), the largest telescope in the world at that time. It was placed atop a mountain, as are now modern observatories.

\section{References}

Bacchus, P. 1992, Observations \& Travaux, 23, 3

Badoureau, A. 2005, Le Titan moderne (Nantes: Actes Sud)

Butcher, W. 2006, Jules Verne: The Definitive Biography (New York: Thunder's Mouth Press)

Crovisier, J. 2005a, in Jules Verne, les Machines et la Science, edts P. Mustière, \& M. Fabre (Nantes: Coiffard), 66

Crovisier, J. 2005b, L'Astronomie, 119, 312

Garcet, H. 1854, Leçons nouvelles de Cosmographie (Paris: Dezobry \& Magdeleine)

Guillemin, A. 1866, La Lune (Paris: Hachette)

Kragh, H. 2009, J. Hist. Ast., 40, 1

Le Lay, C. 2005, in Jules Verne, les Machines et la Science, edts P. Mustière \& M. Fabre (Nantes: Coiffard), 159

O'Connell, D.J.K. 1958, The Green Flash and Other Low Sun Phenomena (Amsterdam: North Holland)

Sauzereau, O. \& Giton, C. (eds) 2006, Revue Jules Verne, 21

Verne, J. 1873, Bull. Soc. Géog. 6, 423 